\title{
Management and treatment of hepatitis $B$ virus in patients with HIV infection: A practical guide for health care professionals
}

\author{
Marina B Klein MD MSc${ }^{1}$, Jean-Guy Baril MD²,3* , Marc-André Charron $\mathrm{MD}^{2,3}$, Claude Fortin $\mathrm{MD}^{5}$, \\ Richard Lalonde $\mathrm{MD}^{1 *}$, Marie-France Matte ${ }^{6 *}$, Marc Poliquin $\mathrm{MD}^{5}$, Annie Talbot MD², , Rachel Therrien ${ }^{7 *}$, \\ Cécile Tremblay $\mathrm{MD}^{7,8 *}$, Benoît Trottier $\mathrm{MD}^{3,9 *}$, Irina Tsarevsky ${ }^{4 *}$, Jean-Pierre Villeneuve $\mathrm{MD}^{10}$
}

\begin{abstract}
MB Klein, J-G Baril, M-A Charron, et al. Management and treatment of hepatitis $B$ virus in patients with HIV infection: $A$ practical guide for health care professionals. Can J Infect Dis Med Microbiol 2011;22(3):88-96.
\end{abstract}

The management and treatment of HIV and hepatitis B virus (HBV)coinfected patients present specific challenges for clinicians. The morbidity and mortality related to these concomitant infections are growing concerns, while the use of antiviral drugs effective against both viruses complicates therapeutic decision making. The present document provides guidelines for physicians regarding care and treatment of patients coinfected with HIV and HBV. Primary prevention of HBV in HIV-positive patients is achieved through appropriate vaccination schedules. Follow-up before treatment of HBV may include liver biopsy, screening for hepatocellular carcinoma and testing for esophageal varicies in cases of cirrhosis. In HBV-infected patients requiring treatment, recommendations regarding initiation, duration and choice of first-line drugs are made. Finally, in the case of resistance, appropriate alternative therapies are necessary.

Key Words: Antiretroviral therapy; Hepatitis B; HIV; HIV coinfection; Resistance; Vaccination

\section{La prise en charge et le traitement du virus de l'hépatite $B$ chez des patients ayant une infection par le VIH : un guide pratique pour les professionnels de la santé}

La prise en charge et le traitement des patients co-infectés par le VIH et le virus de l'hépatite $\mathrm{B}(\mathrm{VHB})$ comportent des défis précis pour les cliniciens. La morbidité et la mortalité liées à ces infections concomitantes sont de plus en plus inquiétantes, tandis que l'utilisation d'antiviraux efficaces contre les deux virus complique les décisions thérapeutiques. Le présent document contient des lignes directrices pour les physiciens au sujet des soins et du traitement des patients co-infectés par le VIH et le VHB. La prévention primaire du VHB chez les patients atteints du VIH s'obtient par un calendrier de vaccination bien planifié. Le suivi avant le traitement du VHB peut inclure une biopsie hépatique, le dépistage du carcinome hépatocellulaire et des tests en vue de déceler des varices œesophagiennes en cas de cirrhose. À l'égard des patients infectés par le VHB qui ont besoin d'être traités, on présente des recommandations portant sur l'amorce, la durée et le choix des médicaments de premier recours. Enfin, en cas de résistance, de nouvelles thérapies pertinentes s'imposent.

$\mathrm{N}$ early $10 \%$ of people living with HIV are also infected with hepatitis B virus (HBV) (1-4). The management and treatment of HIV and HBV-coinfected patients, however, present specific challenges for clinicians. The natural history of HBV is modified in the presence of HIV, and the rate of chronic HBV infection is significantly higher among HBV-HIV-coinfected patients: 25\% compared with 5\% in HIV-negative patients (5). Additionally, the treatment of HBV in HIV-HBV-coinfected patients is challenging because the use of antiviral drugs effective against both viruses may complicate therapeutic decision making. Meanwhile, increased survival rates of HIV-positive patients following the availability of highly active antiretroviral therapy have allowed liver complications related to HBV to emerge as an important cause of morbidity and mortality among HIV-positive patients (6). Much of the current literature has focused on treatment options for HIV-HBV-coinfected patients. While the present article

\begin{abstract}
does address treatment recommendations, it goes further by providing a comprehensive management strategy including recommendations for HBV prevention, use of liver biopsy and screening for hepatocellular carcinoma (HCC).

The present article summarizes the recommendations in "La prise en charge et le traitement des personnes co-infectées par le virus de l'immunodéficience humaine (VIH) et de l'hépatite B (VHB). Guide pour les professionnels de la santé du Québec" - a practical treatment guide developed by the Comité consultatif sur la prise en charge des personnes vivant avec le VIH (Consultant Committee). This Quebecbased panel includes members with extensive experience in the care of HIV patients, infectious diseases specialists and hepatologists. The panel is mandated by the Quebec Ministry of Health and Social Services to establish clinical guidelines for the management and treatment of persons living with HIV.
\end{abstract}

${ }^{1}$ Division of Infectious Diseases and Immunodeficiency Service, McGill University Health Centre; ${ }^{2}$ Clinique médicale du Quartier Latin; ${ }^{3}$ Unité hospitalière de recherche, d'enseignement et de soins sur le sida, Centre hospitalier de l'Université de Montréal, Hôpital Saint-Luc; ${ }^{4}$ Service de lutte contre les infections transmissibles sexuellement et par le sang, ministère de la Santé et des Services sociaux; ${ }^{5}$ Unité hospitalière de recherche, d'enseignement et de soins sur le sida, Centre hospitalier de l'Université de Montréal, Hôpital Notre-Dame; ${ }^{6}$ Programme National de Mentorat sur le VIH-Sida; ${ }^{7}$ nité hospitalière de recherche, d'enseignement et de soins sur le sida, Centre hospitalier de l'Université de Montréal, Hôpital Hôtel-Dieu de Montréal; ${ }^{8}$ Association des médecins microbiologistes infectiologues du Québec; ${ }^{9}$ Clinique médicale L'Actuel, Montréal; ${ }^{10}$ Centre hospitalier de l'Université de Montréal, Hôpital Saint-Luc, Montréal, Québec

* Members of the Comité consultatif sur la prise en charge clinique des personnes vivant avec le VIH

Correspondence and reprints: Dr Marina B Klein, Division of Infectious Diseases and Immunodeficiency Service, McGill University Health Centre, 3650 Saint Urbain, Montreal, Quebec H2X 2P4. Telephone 514-843-2090, fax 514-843-2092, e-mail marina.klein@mcgill.ca 


\section{METHODS}

These recommendations are based on a review of published literature and data presented at international conferences before March 2009. The literature was searched in Medline and PubMed. International conferences include all major international conferences on HIV and hepatology. In cases in which published evidence was lacking, expert opinions were also taken into consideration. Recommendations were obtained through consensus and were graded according to the strength and type of evidence available to support them (Table 1). A medical writing subcommittee (authors of the present article) was established to summarize the recommendations. The final article was reviewed and endorsed by the Consultant Committee.

\section{NATURAL HISTORY AND BIOLOGICAL MARKERS OF HBV INFECTION}

HBV infection can cause acute, fulminant or chronic hepatitis, liver cirrhosis and HCC. Perinatally or childhood-acquired HBV infection usually causes subclinical or anicteric acute hepatitis and is associated with high rates of chronicity (30\% to $90 \%$ of cases), whereas adult-acquired infection causes acute symptomatic hepatitis in approximately $30 \%$ of patients and is associated with low risk of chronicity (less than 5\%) in HIV-seronegative individuals (7). Fulminant hepatic failure is rare $(0.1 \%$ to $0.5 \%$ of patients), but acute coinfection with other hepatitis viruses increases the risk of fulminant hepatitis (8).

Viral proteins and DNA markers that are important for the management and treatment of HBV include surface antigen (HBsAg), an indicator of active HBV infection, and surface antibody (anti-HBs), a neutralizing antibody and a marker of protection and recovery from the infection. Anti-HBs and HBsAg may both be undetectable during the 'window period' of early acute HBV infection $(9,10)$ and, in certain cases, HBsAg and a non-neutralizing form of anti-HBs can be detected simultaneously.

The core antigen $(\mathrm{HBcAg})$ is an intracellular antigen expressed in infected hepatocytes, and cannot be detected in the serum, while the core antibody (anti-HBc) can be detected during the course of HBV infection and is useful as a marker of naturally acquired infection. Hepatitis B e antigen ( $\mathrm{HBeAg}$ ) is produced from the proteins of the core and precore regions, and is usually considered to be the marker of $\mathrm{HBV}$ replication and infectiousness. Seroconversion from $\mathrm{HBeAg}$ to anti-HBe antibody is associated with a lower HBV DNA plasma viral load and recovery from the hepatic disease $(11,12)$, except among patients who develop chronic HBeAg-negative hepatitis (13). HBV DNA is an indication of the presence and degree of viral replication.

HBV infection that resolves within six months is said to be acute, and occurs more often in immunocompetent individuals than in HIVinfected persons. In the absence of resolution within six months, the infection becomes chronic (14). Chronic HBV infection is a dynamic process typically characterized by four phases (2).

The first, the immunotolerant phase, is similar to the incubation period in acute infection. During this period, viral replication is intense and host response is weak. This phase is characterized by the presence of $\mathrm{HBs} \mathrm{Ag}, \mathrm{HBeAg}, \mathrm{HBV}$ DNA level greater than $10^{6} \mathrm{IU} / \mathrm{mL}$, normal alanine aminotransferase (ALT) levels and little histological evidence of infection. This phase is particularly common in persons infected at birth and may last for decades. The immunotolerant phase infrequently occurs in those infected as adults.

The second phase, the immunocompetent phase, is defined by a specific HBV immune response leading to hepatocyte necrosis. This period is characterized by the presence of $\mathrm{HBs} A g, \mathrm{HBeAg}, \mathrm{HBV}$ DNA level greater than $10^{4} \mathrm{IU} / \mathrm{mL}$ and an increase in ALT levels, resulting in liver inflammation, which can lead to fibrosis, cirrhosis and other complications. This phase may also be punctuated by abortive episodes of seroconversion during which $\mathrm{HBeAg}$ disappears and reappears sequentially.

During the third phase, the inactive carrier phase, HBeAg disappears, and anti-HBe emerges. This seroconversion occurs spontaneously in 5\% to $15 \%$ of cases annually $(8,15,16)$. Patients younger than 40 years of age

\section{TABLE 1}

\section{Classification codes of the recommendations and their descriptions}

\begin{tabular}{ll}
\hline \multicolumn{2}{l}{ Strength of recommendation } \\
\hline A & The drug or treatment should always be offered \\
B & The drug or treatment should usually be offered \\
C & The application of this recommendation is optional \\
D & The drug or treatment should generally not be offered \\
E & The drug or treatment should never be offered \\
Basis for recommendation \\
\hline I $\quad$ At least one randomized controlled clinical trial \\
II $\quad$ Uncontrolled clinical trials, cohort or case-control studies \\
III $\quad$ Expert opinions
\end{tabular}

and those with high levels of ALT, low levels of HBV DNA and an absence of cirrhosis are more likely to undergo seroconversion.

Once a person has become an inactive carrier, four scenarios are possible including progression to the fourth phase (clearance of $\mathrm{HBsAg}$ ):

1. Approximately two-thirds of patients will experience a prolonged remission with a good prognosis.

2. A few will clear HBsAg. These patients are effectively cured of the virus. Some patients having cleared HBsAg will continue to be positive for HBV DNA. These cases are often referred to as occult HBV and are characterized by the presence of a low HBV DNA viral load, presence of anti-HBc and absence of $\mathrm{HBsAg}$ and anti-HBs.

3. Five per cent to $10 \%$ will experience a reactivation of $\mathrm{HBV}$ accompanied by a reversion to $\mathrm{HBeAg}$. This is more common among immunosuppressed patients and those undergoing chemotherapy.

4. Several will experience a reactivation of $\mathrm{HBV}$ without a reversion to HBeAg. These cases of chronic hepatitis are said to be $\mathrm{HBeAg}$ negative and are a result of mutations in the basal core promoter or precore regions of the viral genome.

The various serological and virological patterns associated with acute and chronic phases of HIV infection are summarized in Table 2.

\section{HIV-HBV COINFECTION}

The natural history of HBV is modified by HIV infection. The rate of chronic HBV infection, for example, is much higher for patients infected with HIV: $25 \%$ compared with 5\% for HIV-negative people (5). This can be explained by the poor immune responses to HBV (17), which often occurs in the presence of low CD4 cell counts $(18,19)$. Lower levels of aminotransferases, a higher rate of HBV replication, a greater persistence of $\mathrm{HBeAg}$ and a more frequent reactivation of HBV (20) have also been observed in patients with concomitant HIV and HBV infections. Additionally, loss of immunity and the reappearance of $\mathrm{HBs} \mathrm{Ag}$ may occur even if patients have developed positive anti-HBs and have seemingly recovered from the disease (0.02 to 0.2 cases per 100 persons-years) (21). This phenomenon, termed seroreversion, can have fatal consequences (21) and arises more often when HIV is poorly controlled.

A high frequency of occult HBV has also been noted within the coinfected population (17). The prevalence of isolated anti-HBc in HIV-positive patients is estimated to be $10 \%$ to $15 \%$ of coinfected persons $(17,22,23)$. For this reason, it is recommended that all HIVpositive patients be tested for anti-HBc (AII). Because of some reports demonstrating high rates of occult replicating HBV infection, it has also been recommended that HBV DNA levels be measured, whenever anti-HBc is detected (CII) (24), although this recently has been brought into question due to a lack of clear clinical benefit (25).

\section{PRIMARY PREVENTION OF HBV IN HIV-POSITIVE PATIENTS BY VACCINATION}

HIV-positive patients are a population at an increased risk of contracting HBV because the infections both have sexual and percutaneous 
TABLE 2

Laboratory characteristics of the stages of acute and chronic hepatitis B virus (HBV) infection

\begin{tabular}{lcccclll}
\hline Anti-HBc & HBsAg & Anti-HBs* & HBeAg & Anti-HBe HBV DNA (IU/mL) & & ALT & Stage \\
\hline+ & + & - & + & - & $>10^{4}$ to $>10^{8}$ & $\mathrm{~N}$ & Incubation during acute infection or immunotolerance \\
+ & + & - & + & - & $>10^{4}$ to $>10^{8}$ & $\mathrm{~N}$ or $\uparrow$ & Immunocompetence (immune clearance) \\
+ & + & - & - & + & $<200$ & $\mathrm{~N}$ & Inactive carrier \\
+ & + & - & - & + & From undetectable to $>10^{8}$ & $\mathrm{~N}$ or $\uparrow$ & HBeAg-negative chronic HBV \\
+ & + & + & + or - & + or - & Detectable & $\mathrm{N}$ or $\uparrow$ & Chronic infection with non-neutralizing anti-HBs \\
+ & - & + & - & + & Undetectable & $\mathrm{N}$ & Resolved HBV and secondary immunity to a natural infection \\
+ & - & - & - & - & Detectable & $\mathrm{N}$ & Occult HBV \\
+ & - & - & - & - & Undetectable & $\mathrm{N}$ & Three possible situations \\
+ & - & + & - & - & Undetectable & $\mathrm{N}$ & Secondary immunity to vaccination against HBV* \\
\hline
\end{tabular}

${ }^{*}$ The antibody response can be measured quantitatively or qualitatively. A surface antibody (anti-HBs) response of 10 IU/mL or more is considered to be protective or, qualitatively, positive. ${ }^{\dagger}$ These tests should only be conducted in the presence of a positive surface antigen (HBsAg) or isolated core antibody (anti-HBC) to exclude occult HBV. ${ }^{\ddagger}$ Three possible situations: May be a resolved acute HBV infection; may represent the test's lack of sensitivity, thus its inability to detect a very low antiHBs level in the plasma; or may suggest a false-positive anti-HBc result. $\uparrow$ Increased; ALT Alanine aminotransferase; Anti-HBe Anti-hepatitis B e antibody; HBeAg Hepatitis B e antigen; N Normal

TABLE 3

Immunization schedules

\begin{tabular}{|c|c|c|c|}
\hline \multicolumn{4}{|c|}{ Recombivax HB (Merck Canada Inc) } \\
\hline Dose & Interval & $\begin{array}{c}\text { Dosage for } \geq 20 \text { years } \\
\text { of age }(40 \mu \mathrm{g} / \mathrm{mL})\end{array}$ & $\begin{array}{c}\text { Route of } \\
\text { administration }\end{array}$ \\
\hline $1^{\mathrm{st}}$ & - & $1.0 \mathrm{~mL}$ & IM \\
\hline $2^{\text {nd }}$ & 1 month after the $1^{\text {st }}$ dose & $1.0 \mathrm{~mL}$ & IM \\
\hline $3^{\text {rd }}$ & 5 months after the $2^{\text {nd }}$ dose & $1.0 \mathrm{~mL}$ & $\mathrm{IM}$ \\
\hline \multicolumn{4}{|c|}{ Engerix-B (GlaxoSmithKline Inc, Canada) } \\
\hline Dose & Interval & $\begin{array}{c}\text { Dosage for } \geq 20 \text { years } \\
\text { of age }(20 \mu \mathrm{g} / \mathrm{mL})\end{array}$ & $\begin{array}{c}\text { Route of } \\
\text { administration }\end{array}$ \\
\hline $1^{\text {st }}$ & - & $2.0 \mathrm{~mL}$ & IM \\
\hline $2^{\text {nd }}$ & 1 month after the $1^{\text {st }}$ dose & $2.0 \mathrm{~mL}$ & $\mathrm{IM}$ \\
\hline $3^{\text {th }}$ & 5 months after the $2^{\text {rd }}$ dose & $2.0 \mathrm{~mL}$ & $\mathrm{IM}$ \\
\hline
\end{tabular}

IM Intramuscular. Adapted from reference 27

routes of transmission. Thus, patients who are infected with HIV and who are not immune to HBV should be vaccinated (AII). Furthermore, cases in which the risk of exposure to HBV is determined to be high (eg, contact with an HBV carrier), it is unnecessary to await the results of serological tests before starting a vaccine series (AIII). Serology should be performed before, or concurrent with, the administration of the first dose of vaccine, and vaccination should continue if the results reveal that the patient is nonimmune (anti-HBs negative) and uninfected with $\mathrm{HBV}$ (anti-HBc and HBsAg negative) (AIII) (26,27).

If HBV DNA testing does not reveal the presence of occult HBV, those with isolated anti-HBc should be vaccinated as anti-HBs-negative patients (AIII) $(26,28)$.

\section{Vaccination and follow-up}

Two inactivated vaccines for hepatitis B are distributed in Canada: Engerix-B (GlaxoSmithKline Inc, Canada) and Recombivax HB (Merck Canada Inc). Only doses containing $40 \mu \mathrm{g}$ of antigen are recommended for people infected with HIV (AII).

The combined vaccine against hepatitis A and B (Twinrix, GlaxoSmithKline Inc, Canada) is generally not recommended for people with HIV because it only contains $10 \mu \mathrm{g}$ of HBV antigen (DIII). It is, therefore, preferable to use monovalent vaccines against hepatitis A and HBV (CIII) (27). Recommended vaccine schedules are shown in Table 3.

Given suboptimal responses to vaccination in coinfected patients, measurement of anti-HBs antibody titres is recommended one to two months (maximum six months) after the final dose of the vaccine series to confirm an immune response (AII) $(26,27)$. A positive immune response is defined as anti-HBs levels greater than $10 \mathrm{IU} / \mathrm{L}$, and this level is considered to be necessary to protect against infection - weak response $1 \mathrm{IU} / \mathrm{L}$ and nonresponse $0 \mathrm{IU} / \mathrm{L}$. The recommended strategy for

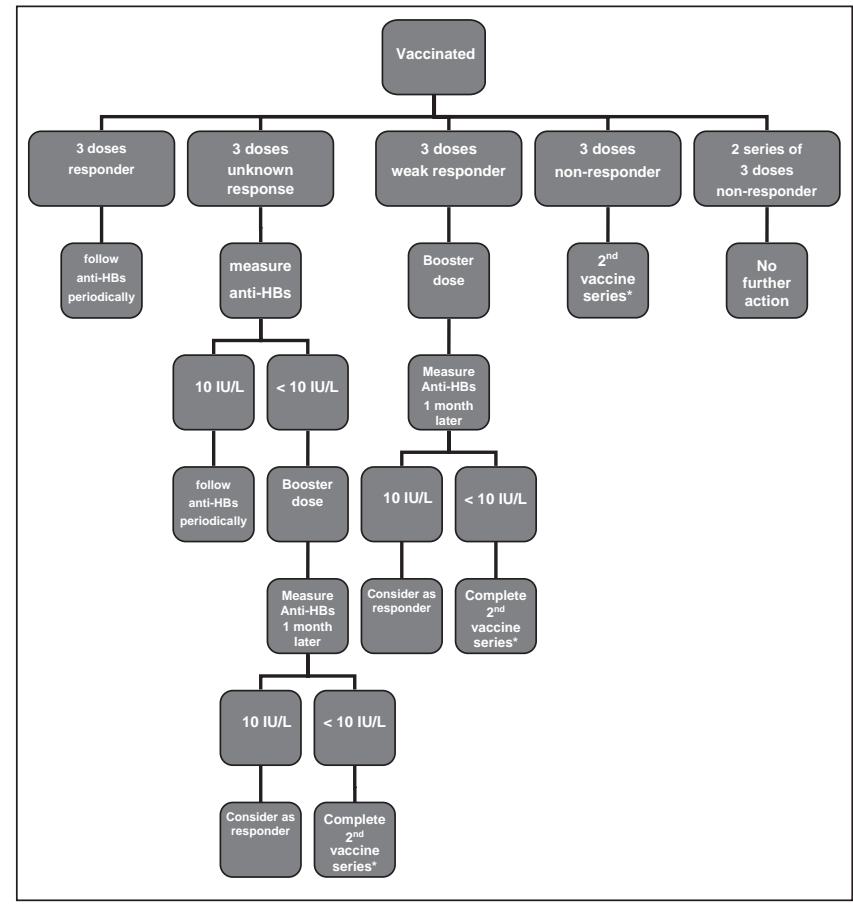

Figure 1) Procedure for following posthepatitis $B$ virus (HBV) vaccination surface antibody (anti-HBs) levels in people living with HIV. *Measure antiHBs one to six months after the end of the vaccine series. Although no specific data exists to guide frequency of measuring anti-HBs in HIV-HBV-coinfected persons following vaccine response, once yearly evaluation has been suggested for patients who have an ongoing risk for HBV acquisition (CIII), as recommended for dialysis patients

revaccination in primary vaccine nonresponders and weak responders is presented in Figure 1. Better immune responses are expected if the additional dose or vaccine series are administered when the CD4+ $T$ cell count is greater than 500 cells/ $\mu \mathrm{L}$ (AII) (29-35). Other strategies, such as four doses and use of an adjuvant, have been attempted to boost immune responses; however, there are insufficient data to make recommendations about their implementation.

Among HIV-infected patients, levels of anti-HBs seem to decline and reach a nonprotective degree (less than $10 \mathrm{IU} / \mathrm{L}$ ) faster than uninfected persons (36). It has, therefore, been suggested that the anti-HBs titres be measured occasionally in immunosuppressed patients, but no specific data about how frequently this should be performed in the setting of HIV have been published (CIII). The data supporting this recommendation have been extrapolated from patients with chronic kidney disease and those on hemodialysis, and 
are favoured for patients who experience an ongoing risk of HBV exposure $(26,27,37,38)$. Overall, given the lower response rates to $\mathrm{HBV}$ vaccination in HIV-infected persons, current vaccination strategies have some limitations in primary HBV prevention, and new approaches require investigation.

\section{INITIAL EVALUATION AND FOLLOW-UP OF PATIENTS COINFECTED WITH HIV AND HBV BEFORE TREATMENT}

The initial evaluation should comprise the following:

- A medical history emphasizing risk factors for HBV, alcohol consumption, and a family history of hepatitis and HCC as well as a physical examination (including a search for stigmata of cirrhosis).

- Determination of whether HBV could have been acquired in the perinatal period, for example, if an individual is from an HBV endemic country or if there is a family history of chronic HBV infection.

- Evaluation to rule out other causes of chronic liver disease (eg, hemochromatosis, autoimmune hepatitis, Wilson's disease, etc.)

- Determination of aminotransferase levels (aspartate aminotransferase and ALT). These can fluctuate considerably; therefore, initial serial measurements are advisable.

- Measurement of HBeAg, anti-HBe, anti-HBs and HBV DNA levels.

- An evaluation of the severity of hepatic disease (bilirubin levels, albumin levels, prothrombin time, and history of bleeding esophageal varices, hepatic encephalopathy or ascites).

- Determination of immunoglobulin $\mathrm{G}$ antibodies to hepatitis A virus and, if negative, vaccination against hepatitis $\mathrm{A}$.

- Serological testing for hepatitis $\mathrm{C}$ virus.

- Testing for antibody to hepatitis D virus is recommended, especially among people who suffer from a severe and fulminant HBV infection or in the presence of elevated aspartate aminotransferase and ALT levels in a patient with HBV DNA lower than $2000 \mathrm{IU} / \mathrm{mL}$.

- Measurement of HBV DNA titres among patients with an isolated anti-HBc (negative HBsAg and anti-HBs) to help diagnose occult $\mathrm{HBV}$, which is more common among immunosuppressed patients (22).

\section{Liver biopsy}

In most cases, a biopsy is not essential before treatment. Instead, the decision to treat is based on HBV DNA viral load and elevation of hepatic transaminase levels. Nevertheless, a biopsy remains the best means of evaluating disease progression related to HBV and may help in guiding treatment in certain contentious cases. For example, a patient older than 40 years of age with a low viral load and transaminases near the upper limit of normal should likely be treated if a biopsy reveals severe fibrosis or cirrhosis. Thus, liver biopsy is most useful in persons who do not meet clear criteria for treatment listed below.

In the future, fibrosis assessment using noninvasive measures will become increasingly important (39); for example, through use of biochemical markers (eg, FibroTest [BioPredictive, France], the aspartate transaminase-to-platelet ratio index and the FIB-4 test) (40) and measurement of hepatic stiffness by impedance (FibroScan, Echosens, France) (41). The utility of Fibroscan, in particular, for staging and quantifying risk of progression to hepatic decompensation shows tremendous promise in the context of hepatitis $\mathrm{C}$ infection, suggesting that such technology may ultimately replace liver biopsy for initial assessment and follow-up $(42,43)$. However, it has not been extensively studied in patients with HBV and HIV coinfection (44).

When to treat chronic HBV in the setting of HIV coinfection Similar to HBV monoinfected patients, people coinfected with HIV and HBV should be reminded to reduce their alcohol consumption due to its effect on the liver (AIII) and should receive treatment for $\mathrm{HBV}$ in any of the following situations:
- HBeAg positive: HBV DNA level greater than $20,000 \mathrm{IU} / \mathrm{mL}$ and elevated ALT levels (CIII). It should be noted that the level of HBV DNA at which treatment is indicated for HBeAg-positive patients is not well defined. Some authors will consider treatment if HBV DNA is greater than $2000 \mathrm{IU} / \mathrm{mL}$. Biopsy may be helpful to guide decision making (45).

- HBeAg negative: HBV DNA viral load greater than $2000 \mathrm{IU} / \mathrm{mL}$ and elevated ALT levels (CIII).

- Significant fibrosis on liver biopsy (eg, F2 or greater), established cirrhosis or moderate to severe hepatic inflammatory infiltrate at liver biopsy and detectable HBV DNA, even in the presence of a low HBV viral load or normal ALT levels (CIII) (46).

- Those who are initiating antiretrovirals for HIV even if HBV DNA is low and/or ALT levels are normal.

Note: The upper limit of normal ALT values vary across laboratories; therefore, specific cut-offs are not provided here. However, it should be noted that recently, accepted 'normal' ALT values have been lowered to $19 \mathrm{IU} / \mathrm{L}$ for women and $30 \mathrm{IU} / \mathrm{L}$ for men (47).

\section{FOLLOW-UP IN PATIENTS NOT UNDERGOING HBV TREATMENT}

For patients in the immunotolerant phase (those who are HBeAg positive and have normal ALT levels), transaminases should be monitored every three to six months to determine when levels become elevated and thus, when treatment should begin (AI). In the presence of repeatedly normal transaminases, it is unnecessary to repeat HBV DNA and serological tests more often than every one to two years. (CII) (47).

Among inactive carriers (HBeAg negative, normal ALT levels and HBV DNA viral load less than $2000 \mathrm{IU} / \mathrm{mL}$ ), an assessment of liver enzymes and HBV DNA should be performed every six to 12 months (BII). It is important to note that in HBeAg-negative patients, ALT levels and HBV DNA may fluctuate considerably. Therefore, to confirm an inactive carrier state, it is important to document normal ALT levels and low levels of HBV DNA consistently. Among HBeAg-negative patients with HBV DNA viral load less than $2000 \mathrm{IU} / \mathrm{mL}$, but abnormal ALT levels, other causes of chronic liver disease should be sought (AII).

In most other cases, treatment is generally indicated (see details below). If a patient does not initiate treatment, monitoring every six to 12 months is recommended (CIII). Specifically, in addition to measuring transaminases and HBV DNA, monitoring for the development of fibrosis is recommended using noninvasive means (see above).

\section{SCREENING FOR HCC}

The risk of developing HCC is greater than $2 \%$ per year among patients with chronic active HBV monoinfection and cirrhosis $(48,49)$. The incidence of $\mathrm{HCC}$ is probably higher among persons coinfected with HIV and HBV (50). Patients who are infected with HBV without evidence of cirrhosis run a lesser, but still significant, risk of developing HCC (between $0.2 \%$ and $0.6 \%$ per year depending on their ethnicity) (51). Screening for HCC every six months, using abdominal ultrasound (BI) and measurement of alpha-fetoprotein (CII), is recommended for all patients who have cirrhosis and for those who may otherwise be at high risk (see below). It has neither been firmly established that ultrasound every six months is more effective than screening every 12 months, nor is it clear whether the measurement of alpha-fetoprotein improves HCC detection rates. Indeed, recent guidelines from the American Association for the Study of Liver Diseases no longer recommend using alpha-fetoprotein for HCC screening, unless ultrasound is difficult to obtain (52). Screening for HCC should be performed for those at risk, even if receiving suppressive HBV treatment because the risk of HCC remains, although it is significantly reduced (CII).

In addition to patients with cirrhosis, all of the following population groups should be tested regularly for HCC if they are infected with HBV: African men and women older than 20 years of age; Asian men older than 40 years of age; Asian women older than 50 years of age; patients with a family history of HCC; patients whose biopsy 
reveals active liver inflammation (more than mild) and patients awaiting liver transplant (47).

Specific follow-up in patients with cirrhosis: Among patients with cirrhosis, in addition to HCC testing, esophageal varices should be sought using endoscopy every two to three years. Beta-blockers should be used as a prophylactic measure against the rupture of varices, and variceal ligation should be performed when large varices are found by endoscopy (BIII) (53).

\section{HBV TREATMENT AND FOLLOW-UP}

Two types of drugs may be used to treat HBV:

- Immunomodulators: interferon-alpha and pegylated interferon.

- Nucleos(t)ide analogues: lamivudine (Heptovir, GlaxoSmithKline Inc, Canada), adefovir (Hepsera, Gilead Science Inc, USA), telbivudine (Sebivo, Novartis Pharmaceuticals Canada Inc), entecavir (Baraclude, Bristol-Myers Squibb, USA), tenofovir (Viread, Gilead Science Inc, USA) and emtricitabine (which is only commercialized in combination with tenofovir in Canada and available as Truvada [Gilead Science Inc, USA]).

\section{Treatment objectives}

The treatment objectives for HIV- and HBV-coinfected patients include the following:

- Eradication of HBV: Elimination of HBV DNA virus in the blood and hepatic tissue and seroconversion to anti-HBs positive. This is generally observed in fewer than $5 \%$ of treated persons.

- Transition toward a less-aggressive stage of the infection: If initially $\mathrm{HBeAg}$ positive, then a seroconversion to $\mathrm{HBeAg}$ negative and anti-HBe positive.

- Reduction of the HBV DNA viral load to $400 \mathrm{IU} / \mathrm{mL}$ or lower.

- Cessation of the progression toward cirrhosis, and regression of the hepatic histology to normalcy.

- Prevention of HCC.

- Prevention of the emergence of a viral strain resistant to antiviral medication.

- Long-term improvement in the tolerance of antiretroviral drugs.

Drugs used to treat HBV in first-line therapy

When HIV treatment is required: If there is an indication to treat HBV, antiretroviral therapy should be initiated regardless of the CD4+ $\mathrm{T}$ cell count (BIII). Current guidelines now recommend earlier treatment for HIV in the setting of chronic HBV $(54,55)$. Because of the dual activity of agents used in the treatment of HIV against HBV, and the possibility for inducing resistance in either virus when used as monotherapy, it is recommended to always initiate a triple antiretroviral regimen, which contains nucleos $(\mathrm{t})$ ide analogues effective against both viruses when treating coinfected persons (CIII). This is the case even in the presence of a low HBV DNA viral load, when there would not normally be an indication to treat HBV (CIII). Whenever anti-HIV and anti-HBV therapies are started simultaneously, tenofovir combined with lamivudine or emtricitabine should be favoured as nucleos(t)ide analogues (BII) (56-59). If their use is impossible due to HIV or HBV resistance or intolerance, the following is recommended:

- If using antiretroviral therapy containing lamivudine, add adefovir to prevent HBV resistance to lamivudine or adefovir (BII) (60), or

- To add one of the following drugs to an effective antiretroviral treatment (eg, when HIV RNA is less than 50 copies $/ \mathrm{mL}$ ): adefovir, telbivudine, pegylated interferon (BII) or entecavir when HIV replication is under control or when the M184V mutation is already present on the HIV genotype (CIII).

When HIV treatment is not initiated: In rare circumstances in which $\mathrm{HBV}$ is treated without treating HIV, therapy with pegylated interferon or adefovir should be offered (BII) (61-63). Telbivudine may also be considered; however, there is insufficient evidence to determine whether it can induce HIV resistance mutations (CIII) $(64,65)$

Interferon-alpha-based therapy can be effective, but is limited to selected subgroups of patients - some of whom may clear HBsAg (52).
Among HBeAg-positive patients, the most important predictors of a response to interferon therapy are high pretreatment ALT levels (greater than twice the upper limit of normal) and lower levels of serum HBV DNA, in which conversion to anti-HBe may be very high (80\% to $90 \%$ ) although HBV DNA persists (66-68). Some studies have suggested that persons infected with HBV genotypes $A$ and $B$ respond better to interferon than those infected with genotypes $C$ and D (69-72). There have been no consistent predictors of response to interferon in $\mathrm{HBeAg}$-negative patients, in whom response rates are substantially lower (less than 15\%). Interferon therapy can be associated with a number of treatment-limiting side effects - some of which may be exacerbated in the setting of HIV. These include myelosuppression, neuropsychiatric toxicities and flares in hepatic enzymes, which can rarely lead to hepatic decompensation (52).

\section{Monitoring of treated patients}

After initiation of treatment, it is necessary to confirm antiviral activity, monitor the effects of treatment on hepatic function and detect the emergence of resistance should it arise. As discussed previously, the disappearance of viremia and the appearance of anti-HBs do not guarantee the eradication of $\operatorname{HBV}(73,74)$.

Thus, follow-up should comprise the following measurements every three months:

- HBV DNA viral load (BII).

- Transaminases (BII).

- Antigens and antibodies specific to HBV (HBsAg, anti-HBs, and for $\mathrm{HBeAg}$-positive cases, $\mathrm{HBeAg}$ and anti-HBe) (BII).

Possible causes of elevated hepatic transaminases after treatment initiation include immune reconstitution syndrome; emergence of $\mathrm{HBV}$, which is resistant to the current treatment; a new hepatitis superinfection or a substance-related hepatoxicity. If drug-induced hepatotoxicity occurs, the medication at fault must be discontinued (AI). In the case of an immune reconstitution syndrome, systemic corticosteroids may be helpful (CIII) (75).

Response to treatment: In HBV monoinfection, a primary response is defined as a reduction in HBV DNA by more than $2 \log _{10}(\mathrm{IU} / \mathrm{mL})$ 24 weeks after the start of treatment (47). Because of low barriers to resistance, an undetectable level of HBV DNA must be achieved by six months for regimens containing lamivudine or telbivudine (if they are the only active agents in the regimen), and by 12 months for those containing adefovir and tenofovir (47). In HIV-coinfected patients, HBV DNA may decline more slowly, especially in patients with preexisting lamivudine resistance. When lamivudine or telbivudine are the only agents active against HBV in the regimen, failure to achieve a reduction in DNA to these levels requires change in therapy. If treatment includes tenofovir, adefovir or entecavir alone or in combination therapy, and HBV DNA remains positive after one year, some clinicians suggest that therapy be continued provided that subsequent HBV DNA values, tested every three months, continue to fall. Many clinicians believe that monotherapy should not be continued if HBV DNA values are greater than $3 \log _{10} \mathrm{IU} / \mathrm{mL}$ after one year of therapy (CIII).

Among HBeAg-positive patients, seroconversion to anti-HBe and normalization of ALT levels are additional important signs of therapeutic response.

Treatment duration: Eradication of the virus is both infrequent and difficult to document because the covalently closed circular DNA genome may persist even after the normalization of all other markers and the seroconversion to anti-HBs. Due to this inability to confirm viral eradication, it is difficult to determine when or whether treatment should be terminated, particularly in the setting of HIV coinfection. Premature cessation may provoke the reactivation of the virus and a serious relapse. Cases of fulminant hepatitis have been reported after the interruption of anti-HBV therapy (73).

The duration of treatment is consequently ill-defined, except in the case of interferon-alpha, which has proven to be effective in studies ranging from 16 to 24 weeks in duration, and in the case of 
TABLE 4

Categories of hepatitis B virus (HBV) treatment failure (as defined by the American Association for the Study of Liver Diseases)

\begin{tabular}{|c|c|}
\hline Term & Definition \\
\hline $\begin{array}{l}\text { Virological } \\
\text { breakthrough }\end{array}$ & $\begin{array}{l}\text { HBV DNA viral load increase of }>1 \log _{10} \text { above nadir during } \\
\text { continued treatment, following a virological response }\end{array}$ \\
\hline Viral & $\begin{array}{l}\text { HBV DNA viral load increase above } 20,000 \mathrm{IU} / \mathrm{mL} \text { or above } \\
\text { pretreatment level during continued treatment, following a } \\
\text { virological response }\end{array}$ \\
\hline $\begin{array}{l}\text { Biochemical } \\
\text { breakthrough }\end{array}$ & $\begin{array}{l}\text { Increase in alanine aminotransferase levels above the } \\
\text { normal upper limit during continued treatment and after } \\
\text { the normalization of hepatic enzyme levels }\end{array}$ \\
\hline $\begin{array}{l}\text { Genotypic } \\
\text { resistance }\end{array}$ & $\begin{array}{l}\text { Detection of mutations, which confer in vitro resistance to } \\
\text { the nucleos(t)ide analogue(s) administered }\end{array}$ \\
\hline $\begin{array}{l}\text { Phenotypic } \\
\text { resistance }\end{array}$ & $\begin{array}{l}\text { In vitro confirmation that a detected mutation decreases the } \\
\text { sensitivity of the nucleos(t)ide analogue(s) administered }\end{array}$ \\
\hline
\end{tabular}

pegylated interferon, for which the recommended duration of treatment is 48 weeks (76). In the case of HBV monoinfection, some experts recommend extending the treatment with nucleos $(\mathrm{t})$ ide analogues, for a six- to 12 -month period following seroconversion, to anti-HBe to maximize the likelihood of a sustained response (47). In some patients, this extended treatment has led to the loss of HBsAg. In monoinfected persons, treatment may be discontinued if seroconversion from $\mathrm{HBsAg}$ to anti-HBs occurs (77). The concomitant treatment of HIV and HBV in coinfected patients, however, generally does not allow for cessation of treatment irrespective of antibody conversion, unless the use of tenofovir and/or lamivudine are no longer required or indicated for the management of HIV.

\section{Resistance}

Failure to respond to therapy can be categorized clinically and virologically (Table 4). HBV DNA viral load must be measured to detect virological failure (BII). Genotypic testing using INNO-LiPA HBV DR (Innogenetics, USA), a reverse hybridization line probe assay, can be used to identify mutations in the HBV genome that are associated with resistance to antiviral drugs. The key mutations associated with HBV resistance are summarized in Table 5.

Genotyping is indicated for patients treated with nucleos $(\mathrm{t})$ ide analogues if one of the following conditions is met:
TABLE 5

Mutations associated with resistance to selected antivirals

\begin{tabular}{lllll}
\hline & \multicolumn{4}{c}{ Polymerase domain } \\
\cline { 2 - 5 } Agent & A & B & C & D \\
\hline Lamivudine & L80V/I & A181T, & M204V/I/S & - \\
Adefovir & L80V/I & A181V/T & - & L229W/V, \\
Entecavir & 169T & L180M & M204V/I & M250V \\
& & T184S/A /I/L/F/G & S202G/I & \\
Telbivudine & - & L180M & M204I & - \\
\hline
\end{tabular}

1. Virological breakthrough: When a patient experiences an increase in HBV DNA viral load of greater than $1 \log _{10}$ (ie, 10 -fold above nadir) while on treatment, and confirmed by a second sample taken one month later (CIII).

2. Primary nonresponse: If the HBV DNA fails to decline by greater than $2 \log _{10}$ after at least six months of therapy.

A large number of HIV-infected patients have previously been exposed to lamivudine as part of their antiretroviral regimens, and are likely to have pre-existing mutations in HBV polymerase that confer resistance to this drug. Details on the rates of resistance associated with drugs used for the treatment of HBV are summarized in Table 6.

In the event of lamivudine resistance, the following options are available in preferential order:

1. Add or substitute tenofovir to lamivudine. This constitutes a first choice when tenofovir also contributes to an effective antiretroviral therapy against HIV (BII).

2. Add adefovir to lamivudine (BII).

3. Add entecavir. This choice may, however, favour the emergence of entecavir-resistant strands. It is generally recommended to discontinue lamivudine when entacavir is used (CII).

In case of failure of adefovir therapy, two options are recommended (also in preferential order):

1. Start an antiretroviral therapy including tenofovir with lamivudine or emtricitabine (BII).

2. When an antiretroviral treatment cannot be offered, adding telbivudine to adefovir is suggested, or using entecavir when no negative impact on HIV is expected (CIII).

\section{TABLE 6}

Details on the rates of resistance associated with drugs used for hepatitis B virus (HBV) treatment

\begin{tabular}{ll}
\hline Agent & Resistance rate (monoinfection) \\
\hline Lamivudine & $15 \%$ to $32 \%$ per year of treatment $(60,78)$ \\
Adefovir & $3 \%$ at 2 years, $6 \%$ at 3 years $(79)$ and $29 \%$ at \\
& 5 years (89) \\
Entecavir $\quad 1 \%$ at 4 years $(92)$
\end{tabular}

Entecavir $\quad 1 \%$ at 4 years (92)

Telbivudine $80 \%$ of patients with a HBV DNA viral load $>3 \log _{10}$ copies/mL after 24 weeks of therapy have developed a resistance to telbivudine vs $2 \%$ of $\mathrm{HBeAg}-$ cases and $3 \%$ of $\mathrm{HBeAg}+$ cases with an undetectable HBV DNA viral load (95)

Tenofovir No case of resistance has been identified at 72 weeks, even in a group of subjects with treatment failure at 24 weeks $(96,97)$

\begin{tabular}{|c|c|}
\hline Coinfection data & Activity if resistance from the start \\
\hline Approximately $20 \%$ per year of therapy $(60,79)$ & In case of resistance to lamivudir \\
\hline $\begin{array}{l}\text { May generate resistance to HBV if used as sole } \\
\text { active agent against HBV in an antiretroviral } \\
\text { treatment (80-82) }\end{array}$ & $\begin{array}{l}\text { preferable to keep lamivudine in subsequent } \\
\text { anti-HBV treatment to prevent resistance to } \\
\text { other agents (83-88) }\end{array}$ \\
\hline $\begin{array}{l}\text { Does not induce HIV resistance when used at a } \\
10 \mathrm{mg} / \text { day dose against HBV }\end{array}$ & $\begin{array}{l}\text { Resistance to adefovir will appear faster in the } \\
\text { presence of lamivudine resistance }(90,91)\end{array}$ \\
\hline $\begin{array}{l}\text { May induce the M184V HIV mutation and should } \\
\text { not be prescribed to coinfected patients unless }\end{array}$ & $\begin{array}{l}1 \%, 10 \%, 16 \% \text { at } 1,2 \text { and } 3 \text { years, respectively, } \\
\text { if there is pre-existing resistance to lamivudine } \\
(94)\end{array}$ \\
\hline
\end{tabular}
their HIV RNA is undetectable or they already have the M184V mutation documented (93)

No data on coinfection, but does not seem to induce mutations in the HIV gene (65)

The presence of mutations induced by lamivudine confer resistance to telbivudine

Induces mutations in the HIV gene, unless it is used as part of an effective anti-HIV therapy
Tenofovir may be effective for patients pretreated with adefovir or lamivudine $(96,97)$

Number in parentheses refer to references. - Negative; + Positive; HBeAg Hepatitis B e antigen; vs Versus 


\section{CONCLUSIONS}

Nearly $10 \%$ of people living with HIV are also infected with HBV. Therefore, screening for HBV is essential for all HIV-infected persons, particularly because immigrants from countries endemic for both viruses represent a growing proportion of HIV infections in Canada. Early vaccination of individuals at risk constitutes a key strategy to prevent this number from rising. Rates of seroprotection, however, remain below those achieved in the absence of HIV infection and, thus, innovative strategies to improve vaccine responses represent an important area for future research. In the setting of HIV coinfection, the natural course of HBV is modified, and chronic infection may result in the potential for serious morbidity and mortality. Virtually all coinfected patients will require treatment for HBV regardless of CD4 cell count. Therefore, patients must be followed closely, and effective drugs, if either infection requires treatment, need to be chosen carefully to avoid the emergence of resistance in both the HIV and HBV genomes. Regardless of whether treatment is initiated, evaluation for cirrhosis and screening for HCC are integral to the management of HBV-coinfected persons to permit early detection and intervention with the goal of reducing serious morbidity and mortality associated with these conditions.

There are many unanswered questions with respect to HIV and HBV coinfection to which research should be directed. For example, what is the long-term natural course of coinfection in the setting of active HBV treatment? What will be the impact of significant previous lamivudine exposure with respect to the development of resistance to tenofovir? What are the optimal strategies for management when no current treatment options remain effective? What is the role for transplantation in the setting of HIV-HBV coinfection?

ACKNOWLEDGEMENTS: The authors thank the other members of the "Comité consultatif sur la prise en charge clinique des personnes vivant avec le VIH" who participated in formulating these guidelines: Pierre Côté, Patrice Junod, Normand Lapointe, Bernard Lessard, Ken Monteith, Alain Piché, Danielle Rouleau, Sylvie Trottier and Chris Tsoukas.

DISCLOSURES: Dr Marina Klein has received grant support from GlaxoSmithKline and Schering-Plough Canada; she has received honoraria/consultancy fees from Abbott, Bristol-Myers Squibb, Boehringer Ingelheim, GlaxoSmithKline, Gilead, Merck, Pfizer and Tibotec ViiV. Dr Jean-Guy Baril has received grant support from Abbott, Bristol-Myers Squibb, Boehringer Ingelheim GlaxoSmithKline, Gilead Merck, Pfizer, Roche and Tibotec. He has received honoraria and consultancy fees from Abbott, Bristol-Myers Squibb, Boehringer Ingelheim GlaxoSmithKline, Gilead Merck, Pfizer and Tibotec. Dr Claude Fortin has received honoraria form Gilead and Tibotec and grant support from Gilead and Pfizer. Dr Benoît Trottier has received consultancy fees from Abbott, Boehringer Ingelheim, Bristol-Myers Squibb, Gilead, GlaxoSmithKline, Merck, Pfizer, Roche and Tibotec. Dr Richard Lalonde has received consultancy fees from Abbott, Merck, Schering-Plough and Tibotec. He has received honoraria form Abbott, Tibotec and ViiV. He has received grant support from Abbott, Boehringer Ingelheim, Bristol-Myers Squibb, GlaxoSmithKline, Merck, Pfizer, Schering-Plough, ViiV and Virochem Pharma. Marie-France Matte and Irina Tsarevsky declare no potential conflict of interest.

\section{REFERENCES}

1. Alter M. Epidemiology of viral hepatitis and HIV co-infection. J Hepatol 2006;44(Supp 1):S6-S9.

2. Konopnicki D, Mocroft A, de Wit S, et al; EuroSIDA Group. Hepatitis B and HIV: Prevalence, AIDS progression, response to highly active antiretroviral therapy and increased mortality in the EuroSIDA cohort. AIDS 2005;19:593-601.

3. Trottier B, Thomas R, Machouf N; International Conference on AIDS. How well do we manage HIV infection in intravenous drug users (IDU). Int Conf AIDS 2004;15.

4. Bamvita J-M. Évolution de la mortalité dans une cohorte de patients VIH positifs de la CMQL, 2007.
5. Gatanaga H, Yasuoka A, Kikuchi Y, Tachikawa N, Oka S. Influence of prior HIV-1 infection on the development of chronic hepatitis B infection. Eur J Clin Microbiol Infect Dis 2000;19:237-9.

6. Nikolopoulos GK, Paraskevis D, Hatzitheodorou E, et al. Impact of hepatitis $B$ virus infection on the progression of AIDS and mortality in HIV-infected individuals: A cohort study and meta-analysis. Clin Infect Dis 2009;48:1763-71.

7. McMahon BJ, Alward WL, Hall DB, et al. Acute hepatitis B virus infection: Relation of age to the clinical expression of disease and subsequent development of the carrier state. J Infect Dis 1985;151:599-603.

8. de Franchis R, Hadengue A, Lau G, et al; EASL Jury. EASL International Consensus Conference on Hepatitis B. J Hepatol 2003;39(Suppl 1):S3-25.

9. Bowden S. Serological and molecular diagnosis. Semin Liver Dis 2006;26:97-103.

10. Douglas DD, Taswell HF, Rakela J, Rabe D. Absence of hepatitis B virus DNA detected by polymerase chain reaction in blood donors who are hepatitis B surface antigen negative and antibody to hepatitis B core antigen positive from a United States population with a low prevalence of hepatitis B serologic markers. Transfusion 1993;3:212-6.

11. Hoofnagle JH, Dusheiko GM, Seeff LB, Jones EA, Waggoner JG, Bales ZB. Seroconversion from hepatitis B e antigen to antibody in chronic type B hepatitis. Ann Intern Med 1981;94:744-8.

12. Bonino F, Rosina F, Rizzetto M, et al. Chronic hepatitis in HBsAg carriers with serum HBV-DNA and anti-HBe. Gastroenterology 1986;90:1268-73.

13. Carman WF, Jacyna MR, Hadziyannis S, et al. Mutation preventing formation of hepatitis $B$ e antigen in patients with chronic hepatitis B infection. Lancet 1989;2:588-91.

14. UpToDate. Serologic responses to HBV infection. $<$ www.uptodate.com> (Accessed on November 4, 2009).

15. Liaw YF, Chu CM, Su IJ, Huang MJ, Lin DY, Chang-Chien CS. Clinical and histological events preceding hepatitis B e antigen seroconversion in chronic type B hepatitis. Gastroenterology 1983;84:216-9.

16. Fattovich G, Rugge M, Brollo L, et al. Clinical, virologic and histologic outcome following seroconversion from HBeAg to anti-HBe in chronic hepatitis type B. Hepatology 1986;6:167-72.

17. Lo Re V III, Frank I, Gross R, et al. Prevalence, risk factors, and outcomes for occult hepatitis B virus infection among HIV-infected patients. J Acquir Immune Defic Syndr 2007;44:315-20.

18. Bodsworth NJ, Cooper DA, Donovan B. The influence of human immunodeficiency virus type 1 infection on the development of the hepatitis B virus carrier state. J Infect Dis 1991;163:1138-40.

19. Gilson RJ, Hawkins AE, Beecham MR, et al. Interactions between HIV and hepatitis B virus in homosexual men: Effects on the natural history of infection. AIDS 1997;11:597-606.

20. Di Martino V, Thevenot T, Colin JF, et al. Influence of HIV infection on the response to interferon therapy and the long-term outcome of chronic hepatitis B. Gastroenterology 2002;123:1812-22.

21. Rouphael NG, Talati NJ, Rimland D. Hepatitis B reverse seroconversion in HIV-positive patients: Case series and review of the literature. AIDS 2007;21:771-4.

22. Hofer M, Joller-Jemelka HI, Grob PJ, Lüthy R, Opravil M. Frequent chronic hepatitis B virus infection in HIV-infected patients positive for antibody to hepatitis B core antigen only. Swiss HIV Cohort Study. Eur J Clin Microbiol Infect Dis 1998;17:6-13.

23. Shire NJ, Rouster SD, Rajicic N, Sherman KE. Occult hepatitis B in HIV-infected patients. J Acquir Immune Defic Syndr 2004;36:869-75.

24. Peters M. Diagnosis and management of hepatitis B virus and HIV coinfection. Top HIV Med 2007;15:163-6.

25. Núñez M. Routine hepatitis B virus DNA testing in human immunodeficiency virus-infected patients with positive hepatitis B core antibody but negative hepatitis B surface antigen is not justified by current evidence. Hepatology 2010;51:1087-8.

26. Comité consultatif national de l'immunisation. Guide canadien d'immunisation. 7ème édition ed. Ottawa: Agence de la santé publique du Canada, 2006.

27. Comité sur l'immunisation du Québec. Protocole d'immunisation du Québec. Ministère de la Santé et des Service sociaux, 2004.

28. British HIV Association. HIV and chronic hepatitis: Co-infection with HIV and hepatitis virus infection. British HIV Association, 2004. 
29. Rey D, Krantz V, Partisani M, et al. Increasing the number of hepatitis $\mathrm{B}$ vaccine injections augments anti-HBs response rate in HIV-infected patients. Effects on HIV-1 viral load. Vaccine 2000;18:1161-5.

30. Fonseca MO, Pang LW, de Paula Cavalheiro N, Barone AA, Heloisa Lopes M. Randomized trial of recombinant hepatitis B vaccine in HIV-infected adult patients: Comparing a standard dose to a double dose. Vaccine 2005;23:2902-8.

31. Pasricha N, Datta U, Chawla Y, et al. Immune responses in patients with HIV infection after vaccination with recombinant hepatitis B virus vaccine. $\mathrm{BMC}$ Infect Dis 2006;6:65.

32. Cornejo-Juárez P, Volkow-Fernández P, Escobedo-López K, et al. Randomized controlled trial of Hepatitis $\mathrm{B}$ virus vaccine in HIV-1-infected patients: Comparing two different doses. AIDS Res Ther 2006;6:9.

33. Ungulkraiwit $\mathrm{P}$, Jongjirawisan $\mathrm{Y}$, Atamasirikul K, Sungkanuparph S. Factors for predicting successful immune response to hepatitis B vaccination in HIV-1 infected patients. Southeast Asian J Trop Med Public Health 2007;38:680-5

34. Veiga AP, Casseb J, Duarte AJ. Humoral response to hepatitis B vaccination and its relationship with T CD45RA+ (naive) and CD45RO+ (memory) subsets in HIV-1-infected subjects. Vaccine 2006;24:7124-8.

35. Wilson CM, Ellenberg JH, Sawyer MK, et al; Adolescent Medicine HIV/AIDS Research Network. Serologic response to hepatitis B vaccine in HIV infected and high-risk HIV uninfected adolescents in the Reaching for Excellence in Adolescent Care and Health cohort (REACH). J Adolesc Health 2001;29(3 Suppl):123-9.

36. Piroth L, Grappin M, Buisson M, Duong M, Portier H, Chavanet P. Hepatitis B virus seroconversion in HIV-HBV coinfected patients treated with highly active antiretroviral therapy. J Acquir Immune Defic Syndr 2000;23:356-7.

37. European Consensus Group on Hepatitis B Immunity. Are booster immunisations needed for lifelong hepatitis B immunity. Lancet 2000;355:561-5.

38. Brook MG, Gilson R, Wilkins E; BHIVA Hepatitis Coinfection Guideline Committee; British HIV Association. BHIVA guidelines on HIV and chronic hepatitis: Coinfection with HIV and hepatitis B virus infection. HIV Medicine 2005;6(Suppl 2):84-95.

39. Kelleher TB, Afdhal N. Assessment of liver fibrosis in coinfected patients. J Hepatol 2006;44(Suppl 1):S126-S131.

40. Myers RP, Tainturier MH, Ratziu V, et al. Prediction of liver histological lesions with biochemical markers in patients with chronic hepatitis B. J Hepatol 2003;39:222-40.

41. Ziol M, Handra-Luca A, Kettaneh A, et al. Non-invasive assessment of liver fibrosis by measurement of stiffness in patients with chronic hepatitis C. Hepatology 2005;41:48-54.

42. Castera L, Forns X, Alberti A. Non-invasive evaluation of liver fibrosis using transient elastography. J Hepatol 2008;48:835-47.

43. Sulkowski MS, Mehta SH, Torbenson MS, et al. Rapid fibrosis progression among HIV/hepatitis $\mathrm{C}$ virus-co-infected adults. AIDS 2007;21:2209-16.

44. Marcellin P, Ziol M, Bedossa P, et al. Non-invasive assessment of liver fibrosis by stiffness measurement in patients with chronic hepatitis B. Liver Int 2009;29:242-7.

45. Bárcena Marugán R, García Garzón S. DNA-guided hepatitis B treatment, viral load is essential, but not sufficient. World J Gastroenterol 2009;15:423-30.

46. Soriano V, Puoti M, Bonacini M, et al. Care of patients with chronic hepatitis B and HIV co-infection: Recommendations from an HIV-HBV International Panel. AIDS 2005;19:221-40.

47. Sherman M, Shafran S, Burak K, et al. Management of chronic hepatitis B: Consensus guidelines. Can J Gastroenterol 2007;21(Suppl C):5C-24C.

48. Realdi G, Fattovich G, Hadziyannis S, et al. Survival and prognostic factors in 366 patients with compensated cirrhosis type B: A multicenter study. The Investigators of the European Concerted Action on Viral Hepatitis (EUROHEP). J Hepatol 1994;21:656-66.

49. Chiaramonte M, Stroffolini T, Vian A, et al. Rate of incidence of hepatocellular carcinoma in patients with compensated viral cirrhosis. Cancer 1999;85:2132-7.

50. Bräu N, Fox RK, Xiao P, et al. Presentation and outcome of hepatocellular carcinoma in HIV-infected patients: A U.S.-Canadian multicenter study. J Hepatol 2007;47:527-37.
51. Laboratoire de santé publique du Québec (LSPQ). Registre MADO dépersonnalisé. Extraction au registre fait par le Bureau de Surveillance et de Vigie (MSSS), 2007.

52. Lok ASF, McMahon BJ. Chronic hepatitis B: Update 2009. Hepatology 2009;50:661-2.

53. Garcia-Tsao G. Prevention and management of gastroesophageal varices and variceal hemorrhage in cirrhosis. Hepatology 2007;46:922-38.

54. Department of Health and Human Services. Panel on Antiretroviral Guidelines for Adults and Adolescents. Guidelines for the use of antiretroviral agents in HIV-1-infected adults and adolescents. <www.aidsinfo.nih.gov/ContentFiles/ AdultandAdolescentGL.pdf> (Accessed on February 22, 2011).

55. Rouleau D, Fortin C, Trottier B, et al. Antiretroviral therapy for adults infected with HIV: Guidelines for health care professionals from the Quebec care committee. Can J Infect Dis Med Microbiol 2010;21.

56. Núñez M, Ramos B, Díaz-Pollán B, et al. Virological outcome of chronic hepatitis B virus infection in HIV-coinfected patients receiving anti-HBV active antiretroviral therapy. AIDS Res Hum Retroviruses 2006;22:842-8.

57. Peters MG, Andersen J, Lynch P, et al. Randomized controlled study of tenofovir and adefovir in chronic hepatitis B virus and HIV infection: ACTG A5127. Hepatology 2006;44:1110-6.

58. Schmutz G, Nelson M, Lutz T, et al. Combination of tenofovir and lamivudine versus tenofovir after lamivudine failure for therapy of hepatitis B in HIV-coinfection. AIDS 2006;20:1951-4.

59. Stephan C, Berger A, Carlebach A, et al. Impact of tenofovir-containing antiretroviral therapy on chronic hepatitis B in a cohort co-infected with human immunodeficiency virus. J Antimicrob Chemother 2005;56:1087-93.

60. Benhamou Y, Bochet M, Thibault V, et al. Long-term incidence of hepatitis $B$ virus resistance to lamivudine in human immunodeficiency virus-infected patients. Hepatology 1999;30:1302-6.

61. Johnson RM, Ristig MB, Overton ET, Lisker-Melman M, Cummings OW, Aberg JA. Safety and tolerability of sequential pegylated IFN-alpha2a and tenofovir for hepatitis B infection in HIV $(+)$ individuals. HIV Clin Trials 2007;8:173-81.

62. Sheldon JA, Corral A, Rodés B, et al. Risk of selecting K65R in antiretroviral-naive HIV-infected individuals with chronic hepatitis B treated with adefovir. AIDS 2005;19:2036-8.

63. Di Martino V, Thevenot T, Boyer N, et al. HIV coinfection does not compromise liver histological response to interferon therapy in patients with chronic hepatitis C. AIDS 2002;16:441-5.

64. Low E, Cox A, Atkins M, Nelson M. Telbivudine has activity against HIV-1. AIDS 2009;23:546-7.

65. Avila C, Karwowska S, ChingHa L, Evans TG. Telbivudine has no in vitro activity against laboratory and clinical HIV-1, including 5 clades and drug-resistant clinical isolates. 16th CROI Conference on Retroviruses and Opportunistic Infections. Montreal, February 8 to $11,2009$.

66. Brook MG, Karayiannis P, Thomas HC. Which patients with chronic hepatitis B virus infection will respond to alpha-interferon therapy? A statistical analysis of predictive factors. Hepatology 1989;10:761-3.

67. Perrillo RP, Schiff ER, Davis GL, et al. A randomized, controlled trial of interferon alfa-2b alone and after prednisone withdrawal for the treatment of chronic hepatitis B. The Hepatitis Interventional Therapy Group. N Engl J Med 1990;323:295-301.

68. Lok AS, Wu PC, Lai CL, et al. A controlled trial of interferon with or without prednisone priming for chronic hepatitis $\mathrm{B}$. Gastroenterology 1992;102:2091-7.

69. Janssen HLA. Pegylated interferon alfa-2b alone or in combination with lamivudine for $\mathrm{HBeAg}$-positive chronic hepatitis B: A randomised trial. Lancet 2005;365:123-9.

70. Kao JH, Wu NH, Chen PJ, Lai MY, Chen DS. Hepatitis B genotypes and the response to interferon therapy. J Hepatol 2000;33:998-1002.

71. Wai CT, Chu CJ, Hussain M, Lok AS. HBV genotype B is associated with better response to interferon therapy in $\mathrm{HBeAg}(+)$ chronic hepatitis than genotype C. Hepatology 2002;36:1425-30.

72. Erhardt A, Blondin D, Hauck K, et al. Response to interferon alfa is hepatitis $B$ virus genotype dependent: Genotype $A$ is more sensitive to interferon than genotype D. Gut 2005;54:1009-13. 
73. Bessesen M, Ives D, Condreay L, Lawrence S, Sherman KE. Chronic active hepatitis B exacerbations in human immunodeficiency virus-infected patients following development of resistance to or withdrawal of lamivudine. Clin Infect Dis 1999;28:1032-5.

74. Wursthorn K, Buggisch P, Lutgehetmann M, Zollner B, Petersen J. Temporary HBV resolution in an HIV-coinfected patient during HBV-directed combination therapy followed by relapse of HBV. Antivir Ther 2006;11:647-52.

75. National Institutes of Health (NIH), Centers for Disease Control and Prevention (CDC), HIV Medicine Association of the Infectious Diseases Society of America (HIVMA/IDSA). Guidelines for Prevention and Treatment of Opportunistic Infections in HIV-Infected Adults and Adolescents, 2008:302.

76. AHFS Drug Information. Monograph - peginterferon alpha. American Society of Health-System Pharmacists, 2007.

77. Gilead Sciences. Product Monograph: PrViread (Tenofovir Disoproxil Fumarate Tablets), 2009.

78. Benhamou Y, Bochet M, Thibault V, et al. Safety and efficacy of adefovir dipivoxil in patients co-infected with HIV-1 and lamivudine-resistant hepatitis B virus: An open-label pilot study. Lancet 2001;358:718-23.

79. Hadziyannis SJ, Tassopoulos NC, Heathcote EJ, et al. Long-term therapy with adefovir dipivoxyl for HBeAg-negative chronic hepatitis B. N Engl J Med 2005;352:2673-81.

80. Delaney WE IV, Yang H, Westland CE, et al. The hepatitis B virus polymerase mutation $\mathrm{rtV} 173 \mathrm{~L}$ is selected during lamivudine therapy and enhances viral replication in vitro. J Virol 2003;77:11833-41.

81. Warner N, Locarnini S, Kuiper M, et al. The L80I substitution in the reverse transcriptase domain of the hepatitis B virus polymerase is associated with lamivudine resistance and enhanced viral replication in vitro. Antimicrob Agents Chemother 2007;51:2285-92.

82. Bozdayi AM, Uzunalimoglu O, Türkyilmaz AR, et al. YSDD: A novel mutation in HBV DNA polymerase confers clinical resistance to lamivudine. J Viral Hep 2003;10:256-65.

83. Rapti I, Dimou E, Mitsoula P, Hadziyannis SJ. Adding-on versus switching-to adefovir therapy in lamivudine-resistant $\mathrm{HBeAg}$-negative chronic hepatitis B. Hepatology 2007;45:307-13.

84. Westland CE, Yang H, Delaney WE IV, et al. Activity of adefovir dipivoxil against all patterns of lamivudine-resistant hepatitis B viruses in patients. J Viral Hep 2005;12:67-73.
85. Lampertico P, Viganò M, Manenti E, Iavarone M, Lunghi G, Colombo M. Adefovir rapidly suppresses hepatitis B in HBeAg-negative patients developing genotypic resistance to lamivudine. Hepatology 2005;42:1414-9.

86. Liaw YF, Lee CM, Chien RN, Yeh CT. Switching to adefovir monotherapy after emergence of lamivudine-resistant mutations in patients with liver cirrhosis. J Viral Hep 2006;13:250-5.

87. Chang TT, Gish RG, Hadziyannis SJ, et al. A dose-ranging study of the efficacy and tolerability of entecavir in Lamivudine-refractory chronic hepatitis B patients. Gastroenterology 2005;129:1198-209.

88. Nelson M, Portsmouth S, Stebbing J, et al. An open-label study of tenofovir in HIV-1 and Hepatitis B virus co-infected individuals. AIDS 2003;17:F7-F10.

89. Hadziyannis SJ, Tassopoulos NC, Heathcote EJ, et al. Long-term therapy with adefovir dipivoxil for $\mathrm{HBeAg}$-negative chronic hepatitis B for up to 5 years. Gastroenterology 2006;131:1743-51.

90. Angus P, Vaughan R, Xiong S, et al. Resistance to adefovir dipivoxil therapy associated with the selection of a novel mutation in the HBV polymerase. Gastroenterology 2003;125:292-7.

91. Lacombe K, Ollivet A, Gozlan J, et al. A novel hepatitis B virus mutation with resistance to adefovir but not to tenofovir in an HIV-hepatitis B virus-co-infected patient. AIDS 2006;20:2229-31.

92. Colonno RJ, Rose RE, Pokornowski K, et al. Four year assessment of ETV resistance in nucleoside-naïve and lamivudine refractory patients. April 11-15, 2007.

93. McMahon MA, Jilek BL, Brennan TP, et al. The HBV drug entecavir - effects on HIV-1 replication and resistance. N Engl J Med 2007;356:2614-21.

94. Colonno RJ. Assessment at three years shows high barrier to resistance is maintained in entecavir-treated nucleoside naïve patients while resistance emergence increases over time in lamivudine refractory patients. Hepatology 2006;44(S1):229A-30A.

95. The Globe Study Group. 2-Year GLOBE trial results: Telbivudine is superior to lamivudine in patients with chronic hepatitis B. Gastroenterology 2009;136:486-95.

96. van Bömmel F, Wünsche T, Schürmann D, Berg T. Tenofovir treatment in patients with lamivudine-resistant hepatitis B mutants strongly affects viral replication. Hepatology 2002;36:507-8.

97. van Bömmel F, Zöllner B, Sarrazin C, et al. Tenofovir for patients with lamivudine-resistant hepatitis B virus (HBV) infection and high HBV DNA level during adefovir therapy. Hepatology 2006;44:318-25. 


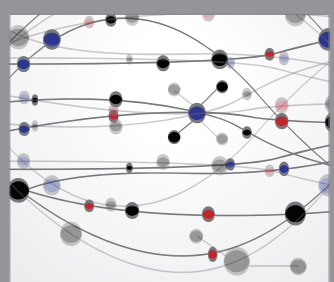

The Scientific World Journal
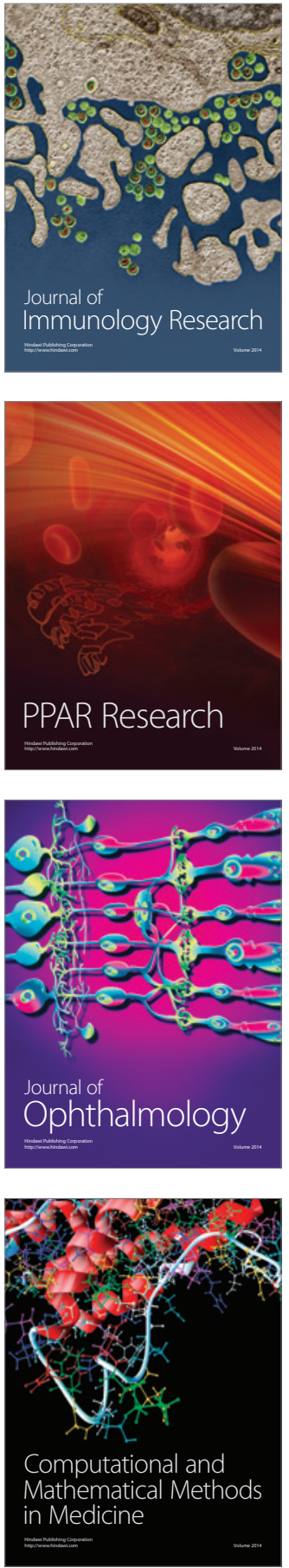

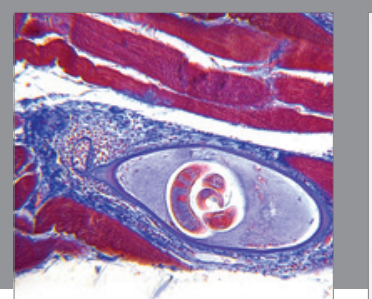

Gastroenterology Research and Practice

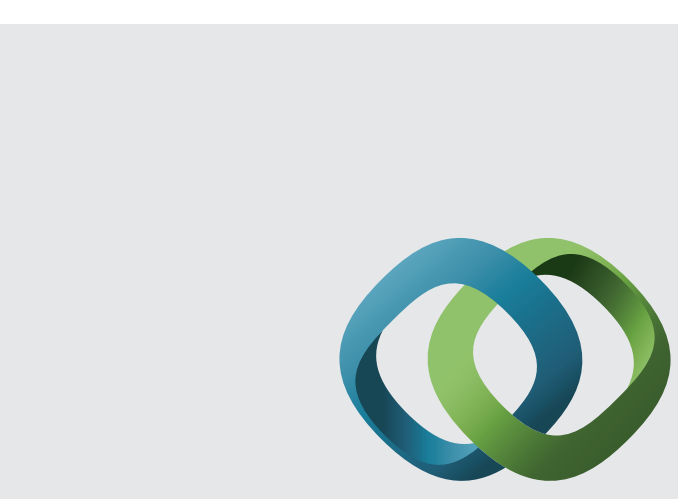

\section{Hindawi}

Submit your manuscripts at

http://www.hindawi.com
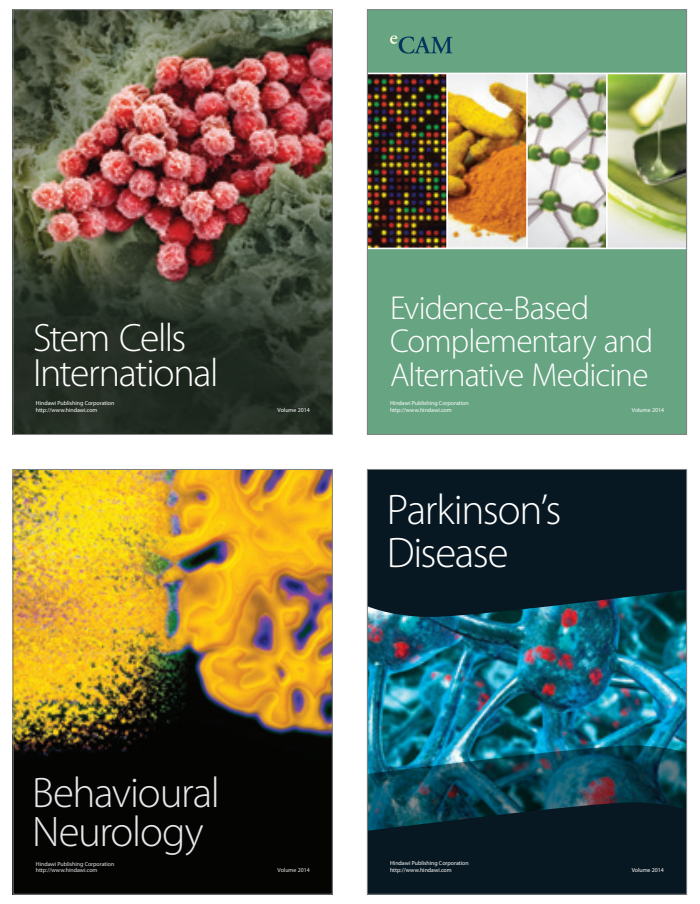
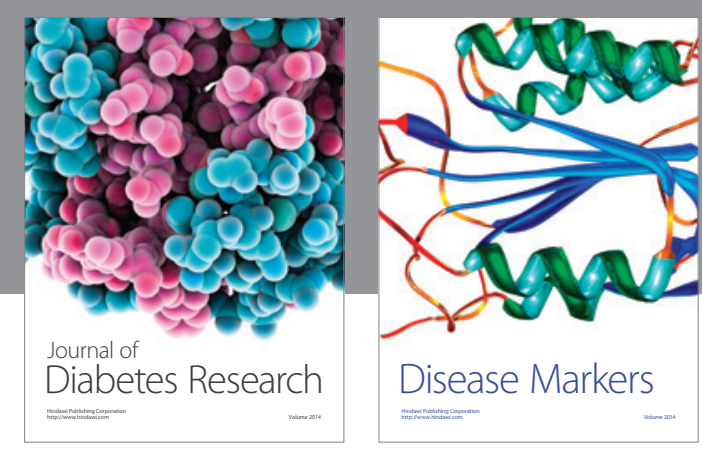

Disease Markers
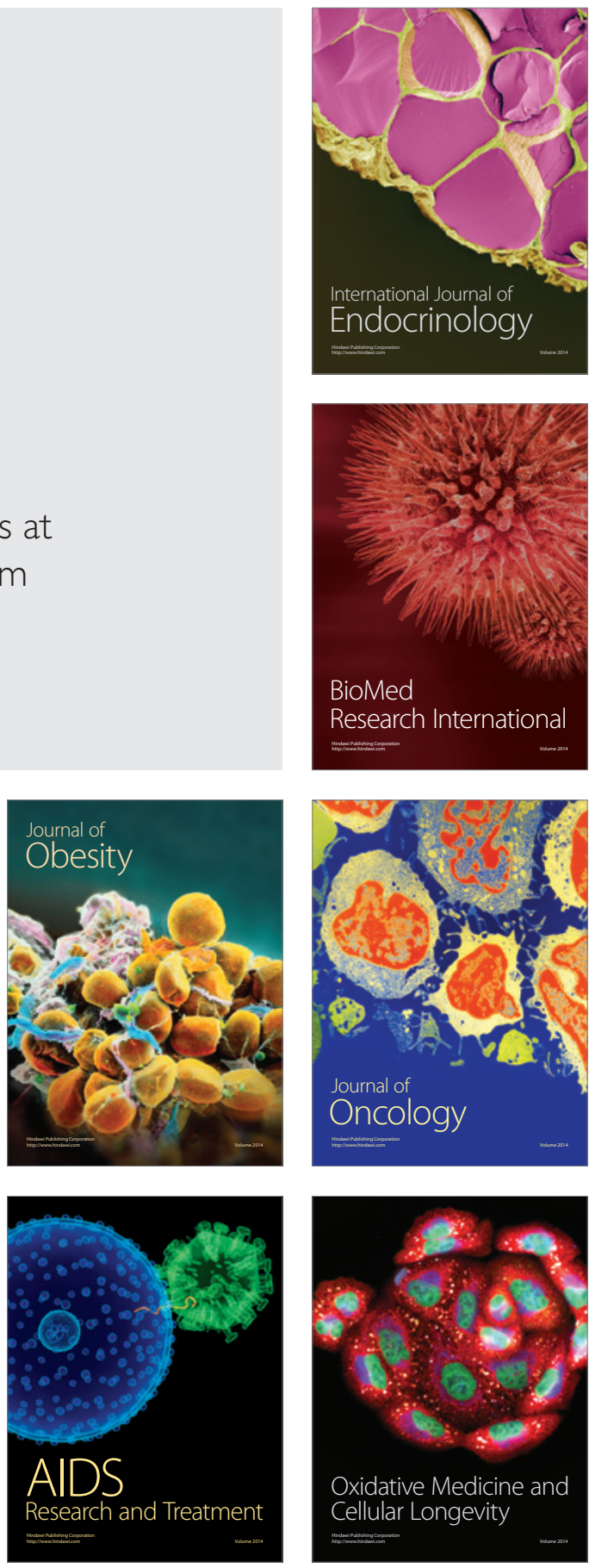